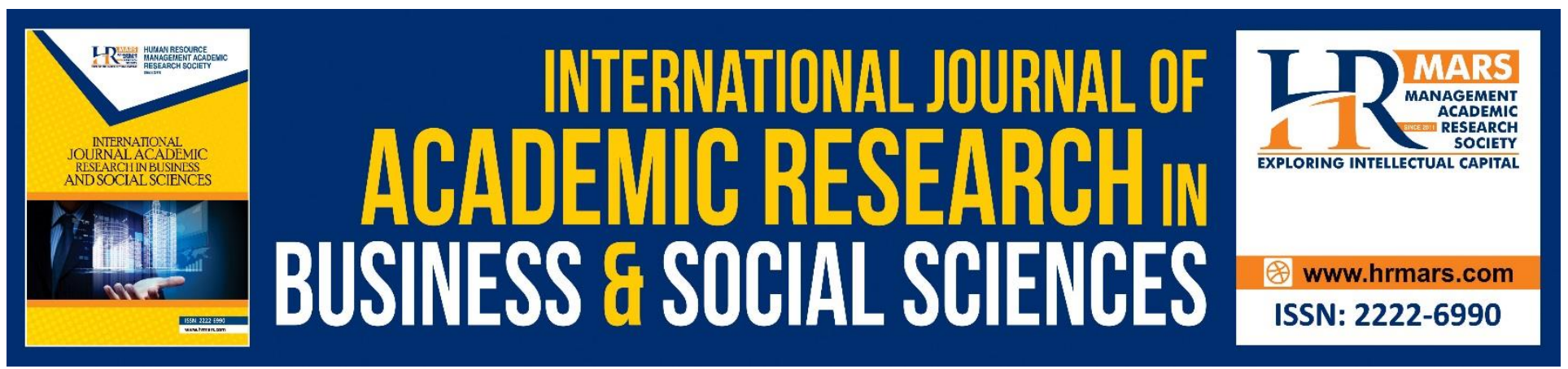

\title{
Students' Attitudes and Perceptions of Learning Mandarin Chinese via Animated Video
}

Suo Yan Ju, Suo Yan Mei

To Link this Article: http://dx.doi.org/10.6007/IJARBSS/v10-i10/7782

DOI:10.6007/IJARBSS/v10-i10/7782

Received: 06 August 2020, Revised: 31 August 2020, Accepted: 19 September 2020

Published Online: 26 October 2020

In-Text Citation: (Ju, \& Mei, 2020)

To Cite this Article: Ju, S. Y., \& Mei, S. Y. (2020). Students' Attitudes and Perceptions of Learning Mandarin Chinese via Animated Video. International Journal of Academic Research in Business and Social Sciences. 10(10), 567-579.

\section{Copyright: (c) 2020 The Author(s)}

Published by Human Resource Management Academic Research Society (www.hrmars.com)

This article is published under the Creative Commons Attribution (CC BY 4.0) license. Anyone may reproduce, distribute, translate and create derivative works of this article (for both commercial and non-commercial purposes), subject to full attribution to the original publication and authors. The full terms of this license may be seen at: $\underline{\text { http://creativecommons.org/licences/by/4.0/legalcode }}$

Vol. 10, No. 10, 2020, Pg. 567 - 579

Full Terms \& Conditions of access and use can be found at http://hrmars.com/index.php/pages/detail/publication-ethics 


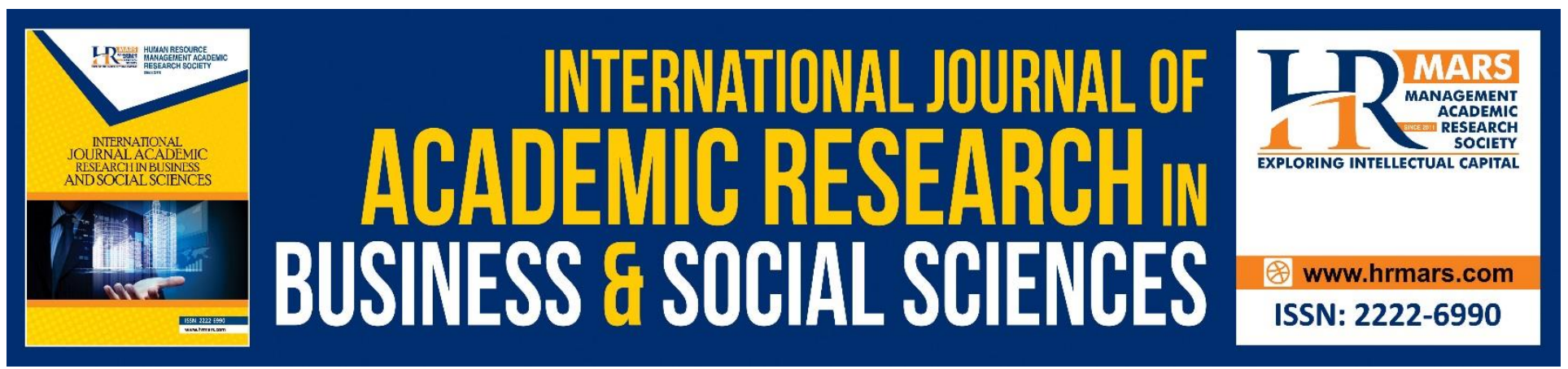

\title{
Students' Attitudes and Perceptions of Learning Mandarin Chinese via Animated Video
}

\author{
Suo Yan Ju \\ Faculty of Major Language Studies, University Sains Islam Malaysia, Bandar Baru Nilai \\ 71800,Nilai, Negeri Sembilan, Malaysia \\ Email: suoyanju@usim.edu.my
}

Suo Yan Mei

Faculty of Languages and Communication, University Pendidika Sultan Idris

Email: fatimahsuo@fbk.upsi.edu.my

\begin{abstract}
The health crisis of COVID-19 has forced many countries around the world to close schools, colleges, and universities. Malaysia's high education administration announced that teaching and learning would be fully online for universities starting from the 1st of June till the end of 2020. This short and long-term disruption shocked by many students and lecturers in the tertiary education sector in Malaysia. Teaching and learning and even assessments have moved fully online, resulting in lot of trials and errors and uncertainty for everyone. Covid-19 has posed significant challenges not only for lecturers, but students as well. There are a plethora of challenges such as technical difficulties, coverage, and speed of the Internet, the quality of teaching, and interactions for students who are not familiar and used to online learning. It is extremely important to attract learners and motivate them in an online learning environment in order to help learners overcome challenges and difficulties in learning.

The present study explored the students' attitudes and perceptions of learning Mandarin via animated videos at a beginner level. Animated video is used to create content covered in online lessons and integrates basic Mandarin vocabulary, sentence structures and enhances learning. Several surveys and semi-structured interviews were used to assess students' attitudes and perceptions towards this method of instruction in online teaching and learning during the COVID-19 pandemic. The findings of the study demonstrated that students kept a positive attitude towards learning Mandarin via animated video. Students expressed that animated video not only enhanced their listening and speaking skills, it also helped them learn Mandarin vocabulary and sentence structures. The findings of this study also suggested that animated video provides Mandarin language teachers with extensive Mandarin vocabulary and sentence structures and enhances learning through fun activities in online teaching.
\end{abstract}

Keywords: Online Learning and Teaching, Animated Video, Mandarin Teaching, E-Learning. 
INTERNATIONAL JOURNAL OF ACADEMIC RESEARCH IN BUSINESS AND SOCIAL SCIENCES Vol. 10, No. 10, 2020, E-ISSN: 2222-6990 @ 2020 HRMARS

\section{Introduction}

Online teaching and learning are not new to the education sector, although many schools and universities have developed their own online teaching and learning methods. However, most of the education sector is still relies heavily on traditional face-to-face interactions in the classroom. Unfortunately, with Covid-19 spreading globally, the education sector has no other choice but to having teaching and learning online fully for the safety and health of educators and students. Compared to face-to-face classroom teaching, there are many advantages of online teaching and learning. The advantages include a flexible schedule and environment, increased self-discipline and responsibility, more academic options, and an opportunity to build technical skills.

However, switching from a traditional classroom and face-to-face teaching and learning to computer-based learning in a virtual classroom makes the learning experience entirely different for students. The changes take time for students to adapt and become accustomed to a computer-based education. Students also encountered many problems such as technical issues, a lack of computer literacy, adaptability, and time-management. Most importantly, there was a lack of motivation, which is an essential requirement in online teaching and learning. Being able to understand and enhance students' motivation of online learning has a significant impact on how educators help the students improve their general performance.

When designing online courses, it is the educators' responsibility to find ways to capture and sustain students' attention and interest and also continue to motivate them to learn online. Creating a blended learning environment to teach, especially teaching a language online, involves technical and pedagogical challenges for language teachers when implementing modern technologies and visual classroom applications. In an online learning environment, most communication between learners and instructors is asynchronous, which leads to an isolated learning context. Some researchers have argued that limited speaking and listening practices in online courses might affect the development of language learners' oral proficiency (Felix, 2001; Hurd,2005; Jaggars, 2014). Sun et al. (2013) also argued that this asynchronous learning could make language learning "extremely difficult, especially when learning a category IV language such as Mandarin Chinese" (p. 162). Online language learning also has less face-to-face meetings, which could directly affect students' perceptions of online language courses. Jin (2004) investigated three web tools in Chinese as a foreign language (CFL) teaching and learning and found that CFL learners' favorite learning style was face-toface communication. This finding was supported by Cheng's (2011) study which found that $78 \%$ of his participants expressed a preference for traditional face-to-face classes over online classes.

In addition, a large amount of self-speaking practices, a lack of peer-to-peer and learner-instructor interactions, and delayed feedback, may slowly decrease learners' motivation to continue with a course (White,2003; Lancashire, 2009; Jiang, 2014).

When it comes to teaching a language subject, target language input plays a significant role (Ellis, 2003), which can be done through a lot of reading and listening. However, with a second language or the teaching of a foreign language, it is more difficult to help students learn and have fun via reading and listening. Therefore, interesting and diverse teaching content plays a significant role that can help students learn the foreign language better, which can be achieved via animation videos. Many types of research have been conducted in the English language which can help language learners with their vocabulary, sentence structure, grammar, and listening skills. (Dickinson, 2001; Penno, et al., 2002; Verdugo \& Belmonte, 2007, Abdo, et al., 2017). Having diverse multimedia can stimulate language 
INTERNATIONAL JOURNAL OF ACADEMIC RESEARCH IN BUSINESS AND SOCIAL SCIENCES Vol. 10, No. 10, 2020, E-ISSN: 2222-6990 @ 2020 HRMARS

learners to be motivated and help them love to learn a language. Moreover, the diversity can help learners to acquire vocabulary more efficiently ((Al-Seghayer, 2001; Jin, 2004).

There is a rapid development of advanced digital technologies combined with multimedia storytelling and animation video, which provides language learners with audio and video input, along with story narrations. These tools are widely used to teach language subjects, especially the English language.

\section{Learning Languages via Animation Videos}

Animated video (cartoons, also known as comics) along with pictures, audio, and video used in language teaching can encourage students to read and improve their motivation to learn (Derrick, 2008). Animated video also provides audio support and visual stimuli. Many studies have been completed on animated video in English language teaching. Yildirim and Fatma (2014) explored the value of animated stories with young English language learners, and found that young English language learners kept a positive attitude towards learning the English language with animated stories. The authors believed that animated stories provided teachers with opportunities to present and recycle vocabulary, grammar, and integrate many activities via animated story themes. Another study was conducted by Krishnan et.al (2018) to develop secondary school English language learners' listening abilities and vocabulary via the use of animated cartoons from YouTube. The study found that the use of 'Animated Cartoons "improved low proficiency English learners' with the acquisition of vocabulary and listening abilities. Egounletia et.al (2018) explored the impacts of cartoons on motivating secondary school English language learners to speak a target language in a classroom. The study found that using cartoons to teach the English language has a positive impact on beginner English as foreign language learners' speaking, listening, reading, and writing abilities. Using cartoons was an efficient means to help language learners' anxiety and motivated beginner English language learners to develop their oral capabilities.

It is important to note that, all the researches mentioned above are related to English language teaching. However, few studies have been done using animated video in other foreign languages. In one study, Chan and Wang (2017) proposed a model that can be used to plan lessons by using anime (Japanese cartoon), as a teaching tool in Japanese as a foreign language classrooms.

In teaching Chinese as a foreign language, little research has been done on animations. Lien. et al. (2011) designed a curriculum by using animated cartoons to teach Chinese as a foreign language and evaluated the effectiveness of the curriculum. Although the study found that the curriculum designed was effective and improved Chinese foreign language learners' performance and level of interest. However, due to the fact that there was a low number of participants and a short time implementation, the designed teaching model does not ensure the same effects will take place in a lengthy period of teaching. Other researchers (Xu, et. al, 2018; Tan, et.al, 2018) only focused on animation in developing learners' orthographic knowledge. $\mathrm{Xu}$, et. al (2018) investigated the comparative effectiveness of reading, animation, and writing in developing foreign language learners' orthographic knowledge of Chinese. The study found that writing and animation of both led to better form recognition of Chinese characters. Tan's (2018) study found that animation can help Chinese language learners in their Chinese character writing and writing skills in general. Although both studies did not explore other aspects of Chinese language teaching, it was a positive development of integrating animation in Chinese language teaching. 
INTERNATIONAL JOURNAL OF ACADEMIC RESEARCH IN BUSINESS AND SOCIAL SCIENCES Vol. 10, No. 10, 2020, E-ISSN: 2222-6990 @ 2020 HRMARS

Integrating animated videos with enjoyable follow-up activities may create an enjoyable learning environment. However, the potential contributions of animated video to a more positive learning environment in teaching Chinese as foreign language classes has not been studied thoroughly. This study, therefore, aimed to investigate attitudes and perceptions of learning basic Mandarin Chinese by integrating animated video among beginner Mandarin Chinese learners.

The objectives of this study are:

1.To investigate the attitudes of beginner Mandarin Chinese learners towards learning Mandarin Chinese via aminated video.

2.To identify the beginner Mandarin Chinese learners' perceptions of language teaching and learning via animated video.

The study attempts to answer the following research questions:

RQ1: What are the attitudes of beginner Mandarin Chinese learners towards learning Mandarin Chinese via animated video?

RQ2: What are beginner Mandarin Chinese learners' perceptions of language teaching and learning via animated video?

Methodology

Participants

The participants were $(n=86)$ university non-native Chinese language learners from various faculties in Malaysia. The participants took a level one Mandarin Chinese as one of the foreign languages elective courses offered by the university. The course was conducted three hours per week with a total of fourteen weeks with four weeks of face-to-face classes and ten weeks of online classes due to the Covid-19 pandemic. The course textbook used at the university was published by the university. The students' Mandarin proficiency level was considered to be at a beginner level, as they did not have any foundation of Mandarin Chinese before they took the course.

Implementation:

The animated videos (Figure 1) were created and posted based on the textbook (I Love Mandarin 1) and used in the course by a language instructor on YouTube.com. The overarching themes that were integrated were basic Mandarin Chinese vocabulary, sentence structures, and functions of the target language. Six animated videos were created and posted in this study for 10 Mandarin Chinese lessons over 10 weeks. The six animated videos created and posted were based on six themes: family members, friends, eating outside, weekend activities, going for holidays, and celebrating festivals. The animated video was created by a cloud-based animation video software called Animker, which allowed the users to create and edit online videos based on pre-built characters and templates. The animated video could be uploaded on social media or downloaded as an mp4 file. The animated video created was in a full multimedia format that included audio (it could be uploaded via own voice or a text placed over the voice by other native speakers' voices by a software), music, and animation that could help students learn new Chinese new vocabulary, grammar, and basic sentence structures. Based on the proposed prototype of the entry-level course design model (Sun et al, 2013), students were required to embark on an "asynchronous instruction" via watching the animated video created and posted before the synchronous interaction online class was conducted in Microsoft Teams. The content of animated video was then discussed via a synchronous interaction and later assessed via an asynchronous assessment to check the progress of students' learning, by using an online quiz platform called.quizzizz.com and live worksheets which the learners completed online. 


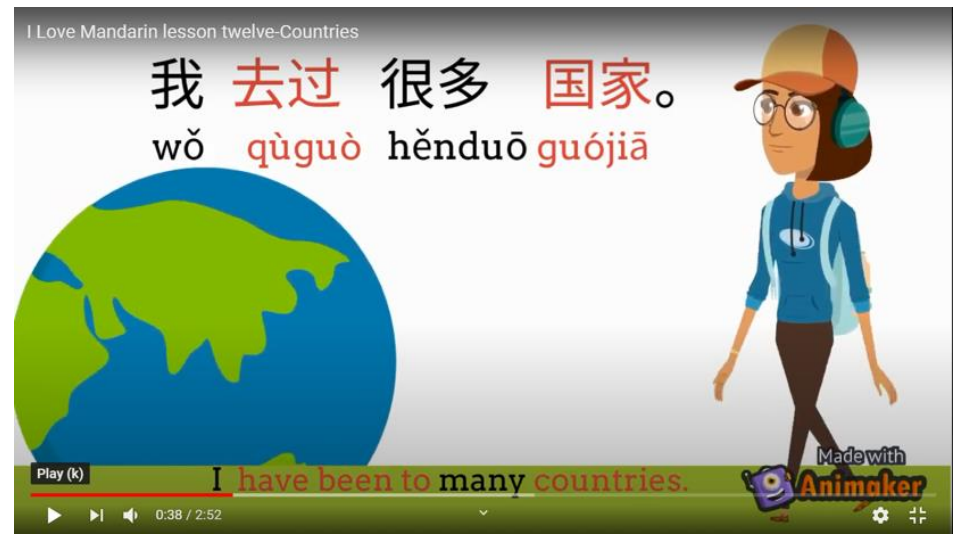

Figure 1: Animated video posted in YouTube

The criteria of creating animated video were proposed by Ellis et.al (2002) which paid attention to the level and variety of language, suitability, and relevance to the content. The researcher tried to create the animated video in an easy and interesting way, in order to attract and help students understand the content in an easy way.

Also, when designing the interactive activities and assessments based on the animated video, special attention was paid to course objectives and learning outcomes. The activities included in the video themes consisted of interactive flashcards, pictures, PowerPoint presentations online games, conversations, etc. to help students become more familiar with the language content.

Data collection

A mix of qualitative and quantitative data instruments was used to explore a clear picture of the perceptions and attitudes of the participants on Mandarin language teaching via an animated video. Multiple data collection tools were used to maintain validity and reliability based on triangulation purposes proposed by Berg (2001). According to Berg, triangulation should not be a combination of all kinds of data, but instead, it's necessary to try to relate them. Therefore, the data collection tools used in this study were: a structured perception questionnaire, an open-end attitude questionnaire, and interviews.

To investigate the perceptions of participants towards learning Mandarin Chinese via the animated video created and posted by the language instructor based on the content textbook used in this course, a self-developed structured perceptions questionnaire was used. The structured perceptions questionnaire consisted mostly of five point-Likert scale items, which required participants to rate each item from $1=$ strongly agree to $5=$ strongly disagree. The questionnaire consisted of 20 items. In addition, an open-end questionnaire was designed by the researcher to obtain more detailed information on the perceptions of participants towards learning Mandarin Chinese via an animated video. Both structured and open-end questionnaires were administered at the end of the study.

The semi-structured interviews were conducted online through an online application, WhatsApp, due to safety and health purposes relating to Covid-19. Patton (2002) suggested that a semistructured interview helps to inquire about an individual's perceptions and experiences through their own judgment and experience. The interview was conducted at the end of the study to investigate the perceptions of participants about the Mandarin language instruction through an animated video created and posted on YouTube. The interview prepared by the researcher included questions related 
to the students' attitudes and perceptions towards learning Mandarin Chinese, the animated video content, integrated activities, and continuous assessment and their concern about online Mandarin lessons. The interview questions were piloted, and necessary modifications to improve clarity and comprehensibility of the questions were made. A total of 10 participants were selected purposely following non-probability sampling described by Merriam (1998). The interview participants were selected from both sex groups, five males and five females, so as collect data from a range of participants with different experiences. For reliability purposes, the participants were interviewed by other Mandarin instructors who taught higher levels of Mandarin Chinese. The interviews were conducted at the end of the semester via WhatsApp calls due to the Covid-19 pandemic, for safety and health purposes. The interviews were also audio-recorded for descriptive data analysis purposes.

\section{Data Analysis}

To determine the students' attitudes and perceptions of learning Mandarin Chinese via animated content, a descriptive analysis was conducted using SPSS (Statistical Package for Social Sciences) for the quantitative data collected via a structured questionnaire. The frequency and percentage values were analyzed for the five parts to describe the overall picture of how students rate their perceptions of learning Mandarin Chinese via animated content at the end of the semester. Data findings were interpreted based on the percentage values that each part of the questionnaire obtained.

Data collected through qualitative instruments were analysed and interpreted through qualitative analysis techniques. According to Bogdan and Biklen (1992), the task of qualitative analysis involves "working with data, organizing them, breaking them into manageable units, synthesizing them, searching for patterns, discovering what is important and what is to be learned and deciding what you will tell others" (p.153). Thus, qualitative data was analysed accordingly.

\section{Findings and Discussions}

The data was collected from different instruments including a structured five point-Likert- type perception and attitude questionnaire, an open-end attitude questionnaire and a semi-structured interview to obtain the findings of students' attitudes and perceptions toward learning Mandarin Chinese via animated video. The findings and related discussions are presented based on the research questions.

The first research question is to investigate the students' attitudes towards learning Mandarin Chinese via animated videos. The findings of data collected from the questionnaire and the semistructured interviews are presented below:

Table 1: Students' attitudes toward learning Mandarin Chinese via animated video

\begin{tabular}{ll}
\hline Enjoyed learning Mandarin via animated video & $\mathbf{1 0 0 \%}$ \\
Watch it before class & $93 \%$ \\
Watch it after class & $68.6 \%$ \\
To learn new vocabulary from animated videos & $95.4 \%$ \\
Use the vocabulary and sentence learnt from animated video in & \\
speaking and writing & $67.4 \%$ \\
Wish to create their own animated video & $63 \%$ \\
\hline
\end{tabular}


INTERNATIONAL JOURNAL OF ACADEMIC RESEARCH IN BUSINESS AND SOCIAL SCIENCES Vol. 10 , No. 10, 2020, E-ISSN: 2222-6990 @ 2020 HRMARS

Participants showed a positive attitude towards learning Mandarin Chinese via animated video created and uploaded by language instructors. The qualitative data collected demonstrated that the majority (93\%) of participants normally watched the animated video before each online class to prepare themselves and obtain ideas on what will be covered in the upcoming online class. The students expressed that watching the animated video before the online class helped them better understand what was covered in class and also, they could actively participate in the online class activities, as indicated by the following students' statements:

\section{Example 1:}

" I watch it before online class so that I have at least a basic idea on what we are going to learn in the online class later."

Example 2:

"I watch it before class because I can easily catch up on what I will learn."

Example 3:

" I usually watch the animated video posted by our teacher before online class because I want to prepare myself about what I am will learn so that I won't be lost in the online class".

More than half $(68.6 \%)$ of participants also watch animated video after class for revision purpose as students expressed as the following:

Example 1:

" sometimes I watch aminated video posted by my teacher after class because I can review what I have learnt from class."

Example 2:

"I watch it after the class to get additional information while I am making notes for revision". Example 3:

"I watch back the video after the class if I don't understand some topics that we have discussed in the class.'

More than half (67.4\%) of the participants used the vocabulary and sentences they pre-learnt from the animated video in their daily speaking and writing. The participants expressed their views below:

Example 1:

"Most of the videos is about daily conversations. I also learnt new words and how to use it in my sentences."

Example 2:

"There are many new words in every video posted, I always learn these new words that I can use them in my speaking and writing."

Example 3:

"to be honest, I learnt a lot of new words and sentences from the animated video posted that I could use in my daily communication and writing."

When asked about whether they wished to create their own animated video that they can share with others who are learning Mandarin Chinese, more than half of participants (63\%) were willing to do so if they had the opportunity and skills. The participants expressed their willingness to create an animated video below: 
INTERNATIONAL JOURNAL OF ACADEMIC RESEARCH IN BUSINESS AND SOCIAL SCIENCES

Vol. 10, No. 10, 2020, E-ISSN: 2222-6990 @ 2020 HRMARS

\section{Example 1:}

"if I have an opportunity, I would like to create my own animated video, because by watching video it helps us to understand more, and we also can share about what we study, and another learner can refer to our video."

Example 2:

"If I have the skills to edit the video, I would like to create the video and share other Mandarin learning, because it can improve my Mandarin knowledge and Chinese Characters."

Perceptions of learning Mandarin via animated video

The participants expressed their opinion on learning Mandarin Chinese via animated video created and posted by their teacher on YouTube. All the participants agreed that the Mandarin Chinese lessons became much easier via watching animated video, because the animated video piqued the learners' attention and the learners focused better during the online lesson. Animated video can also help learners visualize vocabulary, because the video provided subtitles in Chinese characters, pinyin and English, as Figure (2) demonstrated below:

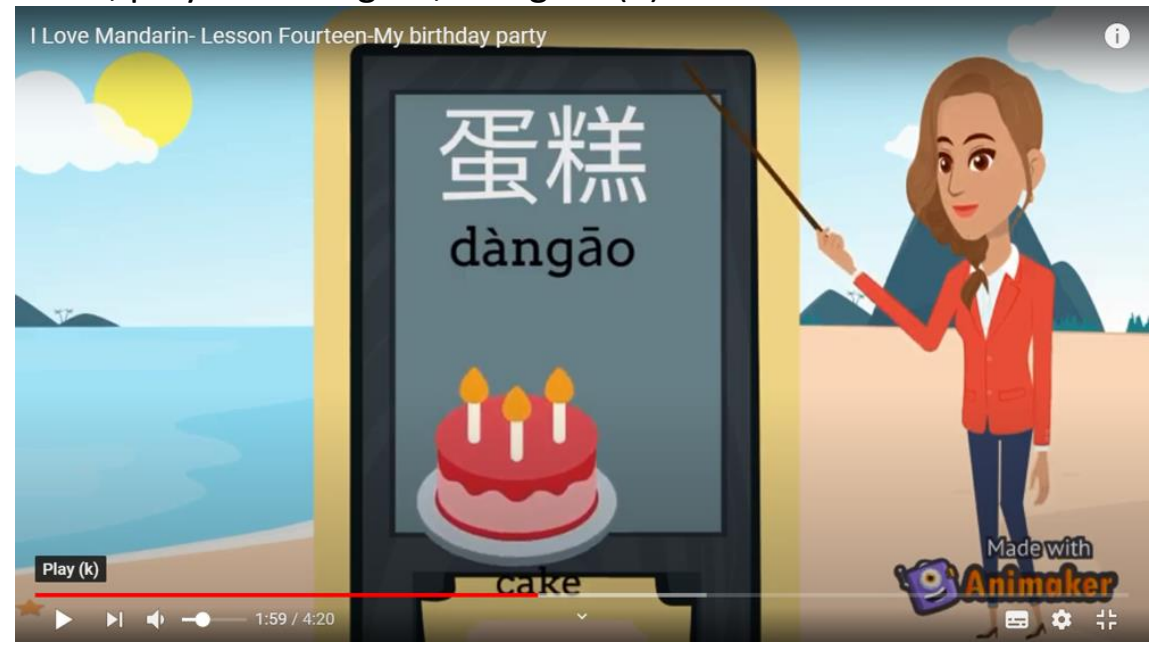

Figure 2: Animated video posted on YouTube

The animated video created was related to the learners' daily lives and it used simple sentences that help learners understand easily.

\section{Students' Perceptions of Animated Video Created and posted on YouTube.}

The quantitative data collected from participants demonstrated that the animated video created and posted by the teacher on YouTube helped Mandarin language learners. It helped with their speaking, listening, writing and reading skills, and also helped them to learn new vocabulary, sentence structures and basic Chinese grammar, as the table showed below: 
INTERNATIONAL JOURNAL OF ACADEMIC RESEARCH IN BUSINESS AND SOCIAL SCIENCES Vol. 10, No. 10, 2020, E-ISSN: 2222-6990 @ 2020 HRMARS

Table 1: Benefits of aminated video on Mandarin language learning

\begin{tabular}{lcccc}
\hline Benefit & f & Rel f & cf & percentile \\
\hline Enhance Listening skills & 49 & 0.57 & 20 & 0.23 \\
Enhance Speaking skills & 46 & 0.53 & 19 & 0.22 \\
Enhance Reading skills & 29 & 0.34 & 19 & 0.22 \\
Enhance Writing skills & 30 & 0.35 & 18 & 0.21 \\
Increase vocabulary & 71 & 0.83 & 18 & 0.21 \\
Learning basic sentence structure & 25 & 0.29 & 17 & 0.20 \\
Improve Grammar knowledge & 17 & 0.20 & 17 & 0.20 \\
\hline
\end{tabular}

The participants perceived that the animated video benefited them in terms of increasing their Chinese vocabulary and enhancing their listening, speaking, writing and reading skills. However, the majority of participants thought that they did not benefit much from animated video for basic sentence structures (79\%) and the improvement of grammar knowledge (80\%). Moreover, more than half of the participants disagreed that animated video benefited them for reading (66\%) and writing (65\%).

A majority of participants (83\%) perceived that animated video could assist their Chinese vocabulary learning. The participants also mentioned in their interviews:

"There are many words I can learn from the video before class, so I can use them in my online class activities, I can understand the lesson better."

The finding supports a study conducted by Ika (2012), that animation videos can improve students' mastery of vocabulary. Students could spell vocabulary, most students were able to pronounce words correctly, students could grasp the meaning well and students could recognize different vocabulary.

More than half of the participants thought that watching the animated video will help them in their speaking (53\%) and listening skills (57\%), as they mentioned in their interview:

"I think animated video benefits me in my listening skills, because I can hear it clearly, the pronunciation is clear, and it helps me to easily understand."

" ........ because I can read, listen and pronounce the word and sentence."

Animations can help students understand complex ideas. A study done by Katchen (2002) illustrated that if educators selected appropriate videos, it can be a useful and an extremely motivational teaching tool for both practicing listening skills and stimulating speaking. The finding also supports Moulic's (2012) study on the positive improvement of students' listening skills by using animation film.

The language skills which do not benefit students from the animated video were writing and reading skills. The results contradicted with Hanifah's (2015) finding that animated video improved junior school students' reading comprehensions. The participants also expressed their opinion that animated video did not help them very much with basic sentence structure and improving their grammar knowledge. This was because they preferred to learn them from the language instructor. Indeed, one of the participants mentioned in the interview as following:

"I prefer grammar and sentence structure by learning with a teacher because I can get detailed learning." 
INTERNATIONAL JOURNAL OF ACADEMIC RESEARCH IN BUSINESS AND SOCIAL SCIENCES Vol. 10, No. 10, 2020, E-ISSN: 2222-6990 @ 2020 HRMARS

Other participants also mentioned that:

"I cannot catch up with the grammar and sentence structure, as I need a more detailed explanation from my teacher."

\section{Conclusion and Recommendation}

In conclusion, the findings of the study showed there are many advantages of using animated video in Mandarin language learning, especially at a beginner level. The animated videos served as an important teaching aid to contextualize the target language in meaningful ways, not only with simple content, but also with the visual and audio stimuli provided. It helped non-native Mandarin language learners with their listening and speaking skills. The animated video could also help learners to learn new Chinese vocabulary and basic sentence structures via interesting relevant topics. If language instructors choose appropriate and suitable animated videos, it will contribute to basic Mandarin language learning, especially with enhancing speaking, listening and vocabulary learning.

It becomes a new trend of using technology with today's younger generation inside and outside the classroom. Technology allows learning beyond the wall of traditional classroom, it not only facilitate learners' language skills, but also engage and motivate beginner Mandarin Chinese foreign language learners to learn the language in a more easy and fun way. Through this study hopefully, Mandarin foreign language educators could revise the curriculum and produce more fun online teaching resource that learners can easily access at their own space. Ultimately,

The study was carried out on beginner level Mandarin language learners but left out if the same finding applies to intermediate and advanced levels. Thus, in-depth studies are needed in the future.

\section{Reference}

Abdo, I. B., \& Al-Awabdeh, A. H. (2017). Animated Videos Prove to be Beneficial in Teaching English Grammar as EFL: A Neurological Study of How Students Learn and Retain English Grammar. Creative Education, 8, 1415-1423. https://doi.org/10.4236/ce.2017.89099

Al-Seghayer, K. (2001). The effect of multimedia annotation modes on L2 vocabulary acquisition: A comparative study. Language Learning \& Technology, 5(1), 202-232.

Bogdan, R. C., \& Biklen, S. K. (1992). Qualitative Research for Education: An Introduction to Theory and Methods. Boston: Allyn and Bacon.

Chan, Y. H., \& Wang, N. L. (2017). The Use of Anime in Teaching Japanese as a Foreign Language. Malaysian Online Journal of Educational Technology. 5(2). https://files.eric.ed.gov/fulltext/EJ1142396.pdf.

Cheng, C. (2011). Online Chinese teaching and learning: A case study. Journal of Technology and Chinese Language Teaching, 2(2), 50-68

Derrick, J. (2008). Using comics with ESL/EFL students. The Internet TESL Journal, 14(7). http://iteslj.org/Techniques/Derrick-UsingComics.html.

Dickinson, D. K. (2001). In D. K. Dickinson \& P. O. Tabors (Eds.). Beginning literacy with language: Young children learning at home and school. (pp257-287). Baltimore, MD: Paul H. Brookes.

Egounletia, P. M., Ulrich O., Sena. \& H., Sonouc, T. K. (2018). Examining the Impacts of Cartoons on Motivating EFL Beginner Students to Speak English Language in Beninese Secondary Schools: The Case Study of Some Secondary Schools in the Atlantic Region. American Scientific Research Journal for Engineering, Technology, and Sciences (ASRJETS).50(1)155-180. 
INTERNATIONAL JOURNAL OF ACADEMIC RESEARCH IN BUSINESS AND SOCIAL SCIENCES Vol. 10, No. 10, 2020, E-ISSN: 2222-6990 @ 2020 HRMARS

Elli, G., Girard, D., \& Brewster, J. (2002). The primary English teacher's guide. Harlow: Penguin English. Ellis, R. (2003). Task-based language learning and teaching. Oxford: Oxford University Press.

Felix, U. (2004). In R. Atkinson, C. McBeath, D. Jonas-Dwyer \& R. Phillips (Eds), Performing beyond the comfort zone: Giving a voice to online communication. [Paper presentation]. In $21^{\text {st } A S C I L I T E ~ C o n f e r e n c e ~(p p . ~ 284-293) . ~ P e r t h . ~}$ http://www.ascilite.org.au/conferences/perth04/procs/felix.html

Hanifah, K. (2015). The Use of Animated video in Improving Students' Reading Skill. Journal of English and Education 3(1), 59-79.

Hurd, S. (2005). Autonomy and the Distance Language Learner. In B. Holmberg, M. A. Shelley, \& C. J. White (Eds.), Languages and distance education: evolution and change (pp. 1-19). Clevedon: Multilingual Matters. Hurd, S. (2007). Anxiety and non-anxiety.

Ika, D. (2012). Animation Video to Improve Students' Vocabulary Mastery. Journal Pendidikan Bahasa Inggris, 1(1). 1-18.

https://media.neliti.com/media/publications/60691-EN-animation-video-to-improvestudents-voca.pdf.

Jiggers, S. S. (2014). Choosing between online and face-to-face courses: Community college student voices. American Journal of Distance Education, 28(1), 27-38. http://doi:10.1080/08923647.2014.867697.

Jiang, S. (2014). Practice and exploration of the Blackboard Learn platform in teaching Chinese online for beginners. Journal of Technology and Chinese Teaching, 5(1), 54-74.

Jin, H. G. (2004). Multimedia effects on Chinese character acquisition. Paper presented at the Conference on Chinese language teaching and Pedagogy, Chicago.

Krishnan, \& Yunus, M. M. (2018). Animated Cartoons to Develop Listening Skill and Vocabulary. International Journal of Engineering \& Technology. 7 (4.21), 20-2.

Katchen, J. E. (1996). Using authentic video in English language teaching: Tips for Taiwan's teachers. Crane Pub.

Lancashire, I. (2009). Teaching literature and language online. New York, NY: Modern Language Association

Lavy, V. (2015), "Do Differences in Schools' Instruction Time Explain International Achievement Gaps? Evidence from Developed and Developing Countries," Economic Journal. 125(588). 397-424. https://doi.org/10.1111/ecoj.12233

Lien, Y. J., Lin, C. H., Chui, G. G. (2011). “Animated teaching: Using cartoons in teaching Chinese as a foreign language. "Journal of Technology and Chinese Language Teaching.2(1), 36-48. http://www.tclt.us/journal/2011v2n1/lien.pdf

Merriam, S. B. (1998). Qualitative research and case study applications in education. San Francisco: Jossey-Bass.

Moulic, M. (2012). Animation Films to Develop Effective Listening Skills in the Classroom. International Peer Reviewed Journal, 2 58-59.

Patton, M. Q. (2002). Qualitative research and evaluation methods (3rd ed.). Thousand Oaks, CA: Sage.

Penno, J. F., Wilkinson, I. A. G., \& Moore, D. W. (2002). "Vocabulary acquisition from teacher explanation and repeated listening to stories: Do they overcome the Matthew Effect?" Journal of Educational Psychology, 94(1), 23-33. 
INTERNATIONAL JOURNAL OF ACADEMIC RESEARCH IN BUSINESS AND SOCIAL SCIENCES Vol. 10, No. 10, 2020, E-ISSN: 2222-6990 @ 2020 HRMARS

Sun, M., Chen, Y., \& Olson, A. (2013). Developing and implementing an Online program: A case study. In B. Zou Chen, M. Xing, C. Xiang, Y. Wang, \& M. Sun (Eds.), Computer- assisted foreign language teaching and learning: Technological advances (pp. 160-187). Hershey, PA: IGI Global. http://doi:10.4018/978-1-4666-2821-2.ch010.

Tan, G. T., Noor, A. A., Mohd, N. H., Mohamad, S., Mohd, F. A., Sanitah, M., \& Mohd, Z. A. H. (2018). Integrating Animations in Chinese Character Writing Based on Cognitive Theory of Multimedia Learning to Promote Students' Writing Skills. International Journal of Interactive Mobile Technology.12(7). https://online-journals.org/index.php/i-jim/article/view/9671

Verdugo, D. R., \& Belmonte, I. A. (2007). "Using digital stories to improve listening comprehension with Spanish young learners of English." Language Learning \& Technology, 11(1), 87-101.

White, C. (2003). Language Learning in Distance Education. Cambridge: Cambridge University Press. http:// doi:10.1017/CBO9780511667312

Xu, Y., Chang, L. Y., Zhang, J., \& Perfetti, C. A. (2013). Reading, Writing, and Animation in Character Learning in Chinese as a Foreign Language. Foreign Language Annals, 46(3), 423-444. http://doi.org/10.1111/flan.12040

Yildirim, R., \& Fatma, P. T. (2014). Exploring the value of animated stories with young English Language learners. The Turkish Online Journal of Educational Technology.13(4), 47-60. 